\title{
Surrealism and the Reliefs of the Sasanian High Priest Kartir
}

\author{
Mohammad Soltani
}

\begin{abstract}
Kartir was the most important religious leader in early Iran at the time of the Sasanian empire. The rock reliefs and inscriptions left by bim contain some important features that occur for the first time in Iranian art history. Specifically, Kartir's rock reliefs reveal that someone who was not a king could still be influential enough to commission a monument in which he was the central figure. Kartir's inscriptions appear next to the reliefs of the previous king, or were even inserted into the same panel. In this way, the traditional construction of these reliefs was altered, as were their respective meanings. Furthermore, Kartir describes an imaginary journey to another world in his inscriptions. The article considers the role of dreams in Kartir's art and what influence this had on this new style of composition, comparing it with what we now call 'surrealism'.
\end{abstract}

Keywords: Sasanian Empire, Kartir, rock relief, inscription, surrealism

The Sasanian dynasty, which represented the last Persian lineage of rulers to achieve hegemony over much of Western Asia before Islam, ruled 224-650 CE. ${ }^{1}$ In 224 the Sasanian dynasty rose in Persis/Fars under Ardashir I (224-239/240 CE). As ruler of Istakhr, Ardashir I claimed the royal title of 'King of Kings'. Ardashir I was the son of Papak, who had seized power in Istakhr in 205/6 CE. Their dynasty took their name from Sasan, the guardian of Anahita sanctuary at Istakhr. The Sasanian dynasty was to rule for over four centuries until the collapse of the empire following the Arab invasions. In 239 Ardashir's son Shapur I (239-270/3 CE) was proclaimed coregent of the empire and became sole King of Kings in 241 CE.

After the death of Shapur I, which should be dated between 270 and 273 CE, three of his sons succeeded to the kingdom. Shapur I had selected one of his two younger sons, Hormizd I (272-273 CE), as his immediate heir to the throne, and had him invested during his lifetime. His brother Bahram I (273-276 CE) succeeded Hormizd a year later. He was Shapur's eldest son. One of the reasons he had been passed over by Shapur I in the royal succession may have been a wariness of Bahram's devout commitment to the

${ }^{1}$ Shahbazi 2005. 
Zoroastrian religion. Although Zoroastrianism, which had developed its doctrines over the past centuries, was the religion of the Persians, Shapur I, like the Persian kings before him, had tolerated other religions unless they conflicted with imperial policy. But, the religious climate changed when Bahram I came to power, possibly with the aid of the priest Kartir. Through Kartir's influence on Bahram I, and also that of his son and successor Bahram II (276-293 CE), the Zoroastrian religion became the sole faith tolerated at the court and across the empire. ${ }^{2}$

Sasanian history survives largely in sources written or translated either by their Roman enemies or by their Muslim conquerors and successors. Furthermore, Sasanian imperial inscriptions are to be found on their reliefs. Some of these reliefs were carved to record the investiture of the ruler, generally by Ahura Mazda, but also by the lesser divinities, Anahita and Mitra. One of the most important Sasanian sources is Shapur I's stone-carved trilingual inscription on the walls of the so-called Kaaba-ye Zardosht (KKZ) at Naqsh-e Rostam in Fars, where he recorded his victories over the Romans. Significantly, inscriptions by the powerful Zoroastrian high priest, Kartir, were also carved on the Kaaba-ye Zardosht and some other places. ${ }^{3}$

Before the discovery and decipherment of Kartir's inscriptions, he was unknown to history. Kartir's inscriptions are carved in a royal style and are unique in being the only inscriptions in Sasanian Iran not carved by a king. The evidence of the bas-reliefs, coupled with the inscriptions, suggests that Kartir exercised greater power than anyone before him, except the king. It would not be too much to suggest that Kartir assumed a position as representative of God on earth, able to transmit the power to rule from God to the king. It seems plausible that with him we have the turning point in the relationship between the Zoroastrian church and the Sasanian state. From the inscriptions of Kartir we see his growing power under successive kings. ${ }^{4}$

Kartir was almost a member of the magus-estate in Ardashir I's reign. He rose to a position of prominence and power in the reign of Shapur I as he states that Shapur, not Ardashir, discovered him and was actually the man who first gave him a position of power and authority in church matters within the magus-estate. His title under this king was not the highest. What Kartir says thereafter about his rise in power and position under Shapur I's successors until he reaches the summit of his career under Bahram II is essentially what one would expect, and is evident through his inscriptions. Kartir states titles which Bahram II conferred upon him: magus-master and judge for the whole empire, master of ceremonies and powerful overlord at the Stakhr fire of Ardashirr's Anahit and Anahit, the lady, Bahram's Soul saviour and Ahuramazda's Magus-master. Regarding his appointment to be judge of the whole empire in the time of Bahram II, it must be noted that the

\footnotetext{
2 Brosius 2006, 147.

${ }^{3}$ Garthwaite 2005, 86.

${ }^{4}$ Frye 1949a, 190.
} 
division between the church and states was not defined as it is in modern times. A Sasanian judge of this sort was not unlike a church official and most, if not all, of Kartir's judging would have been done in heresy trials and other proceedings concerning the church and religion; we have no evidence of any great interference on his part with general civil or military affairs.

Kartir's autobiography stops in the midst of the reign of Bahram II. That he lived to see Narseh come to power is confirmed by Narseh's Paikuli inscription. After that he vanishes once more into oblivion. The new turn which Sasanian history took with Narseh, who hated Bahram I and Bahram II, and from whom all of the Sasanian Kings of Kings who follow him are descended, may in large part account for the disappearing of Kartir's name from the Persian records, even as Narseh attempted to erase the names of the Bahrams. $^{5}$

Regarding Kartir's personal vision journey, and the bust figures that were added to the existing rock reliefs, this article attempts to shed light on what was probably a dream sequence in his rock reliefs through the perspective of the modern art movement known as surrealism. First, however, it is important to provide an explanation of the Sasanian rock reliefs and their significance in the context of Sasanian art.

\section{Sasanian rock reliefs}

The art of the old Near East during the four centuries of Sasanian rule is richly documented. There are major remains of many different types: monumental rock reliefs, silver vessels, stucco architectural decoration and seals. Objects in other media give a varied impression of the art of the period: textile, wall painting, floor mosaics, glass and pottery. The dynastic rock reliefs are unquestionably the most important. In addition to illustrating the stylistic and chronological development of one type of Sasanian art, they offer important evidence concerning the nature of the early Sasanian state, society and religion. ${ }^{6}$

All the great Sasanian bas-reliefs lie in the dynasty's country of origin, Fars, with the exception of the one near Salmas, to the west of Lake Urmia, and those at Taq-e bustan, near Kermanshah. With the exception of a single sculpture at Naqsh-e Rostam, which does not represent a king of the dynasty, all of these monuments are precisely dated by inscriptions or the king's personalized crowns. Thus, we know that they belonged to the third century, with the exception of two bas-reliefs at Taq-e Bustan and the sculptures in the grotto of Khosrow II. ${ }^{7}$

The first Sasanian ruler Ardashir I established the Sasanian tradition of rock carving, which flourished until the reign of Shapur III (383-388 CE), and made an impressive

\footnotetext{
5 Sprengling 1953, 42.

${ }^{6}$ Harper 2011.

${ }^{7}$ Godard 1965, 210.
} 
resurgence under Khosrow II (590-628 CE). Ardashir's rock reliefs differ markedly from the few preserved Parthian specimens (as do his coins) and foreshadow a new monumental form. His three earliest reliefs are in various styles and do not show any clear development. Only the fourth, namely the investiture relief at Naqsh-e Rostam, attains a well-defined form, which reappears in the rock carving of Shapur I and his successors. ${ }^{8}$

These are proclamatory works of art, expressions of political, social and religious concepts. As part of an official state art, the reliefs are conservative in form and conventional in design. The significance of the reliefs is usually clear. Some are victory monuments and record historical events, but the purpose of the majority is the glorification of the dynasty, as represented by the monarch, and of the religion, in the form of the divinity who invests the ruler with kingship. The reliefs clearly demonstrate the close relationship between secular and religious power at the beginning of the period. Changes in the designs and in the styles of carving occur on the rock reliefs. In part, these changes are due to the passage of time, but another important factor is the geographical location of the monuments.

The rock reliefs split up into three groups: the first includes four reliefs of Ardashir I (two at Firuzabad, one at Naqsh-Rajab, one at Naqsh-e Rostam); eight reliefs of Shapur I (two at Naqsh-e Rajab, two at Naqsh-e Rostam, four at Bishapur); one relief of Bahram I (at Bishapur), five reliefs of Bahram II (two at Naqsh-e Rostam, one at Naqsh-e Bahram, one at Bishapur, one at Sarmashad); one relief of Narseh (at Naqsh-e rostam); and one relief of Hormozd II (303-310 CE) (at Naqsh-e Rostam). The second group includes: a relief of Ardashir II (379-383 CE) (at Taq-e Bostan) and the tympanum of the small grotto at Taq-e Bostan representing Shapur II (310-379 CE) and his son Shapur III (383$388 \mathrm{CE})$. The third group includes the sculptures in the cave of Khosrow II (590-628 CE) (at Taq-e Bostan). ${ }^{10}$

First, the art of the third century was still full of elements inherited from Parthian Hellenism; the process of elimination grows during the middle period of the fourth- and fifth centuries; and lastly, the art of the sixth- and seventh centuries, the process nears its end. There was an inheritance from the old Persian period, which was kept alive either in unknown monuments or more latent, during the Seleucid and Parthian periods; but the outward shape of the old Persian motifs had been transformed under the impact of Hellenism, and Sasanian art grew mainly in reaction to that impact. At first still open to Hellenism, it closed itself off more and more, and relapsed into trends of thought that either survived or lived on subconsciously. The three phases mark three degrees or stages in that reaction. At the end of the third phase little remains of Greek thought.

\footnotetext{
${ }^{8}$ Luschey 2011, 377.

${ }^{9}$ Harper 2011.

10 Godard 1965.
} 


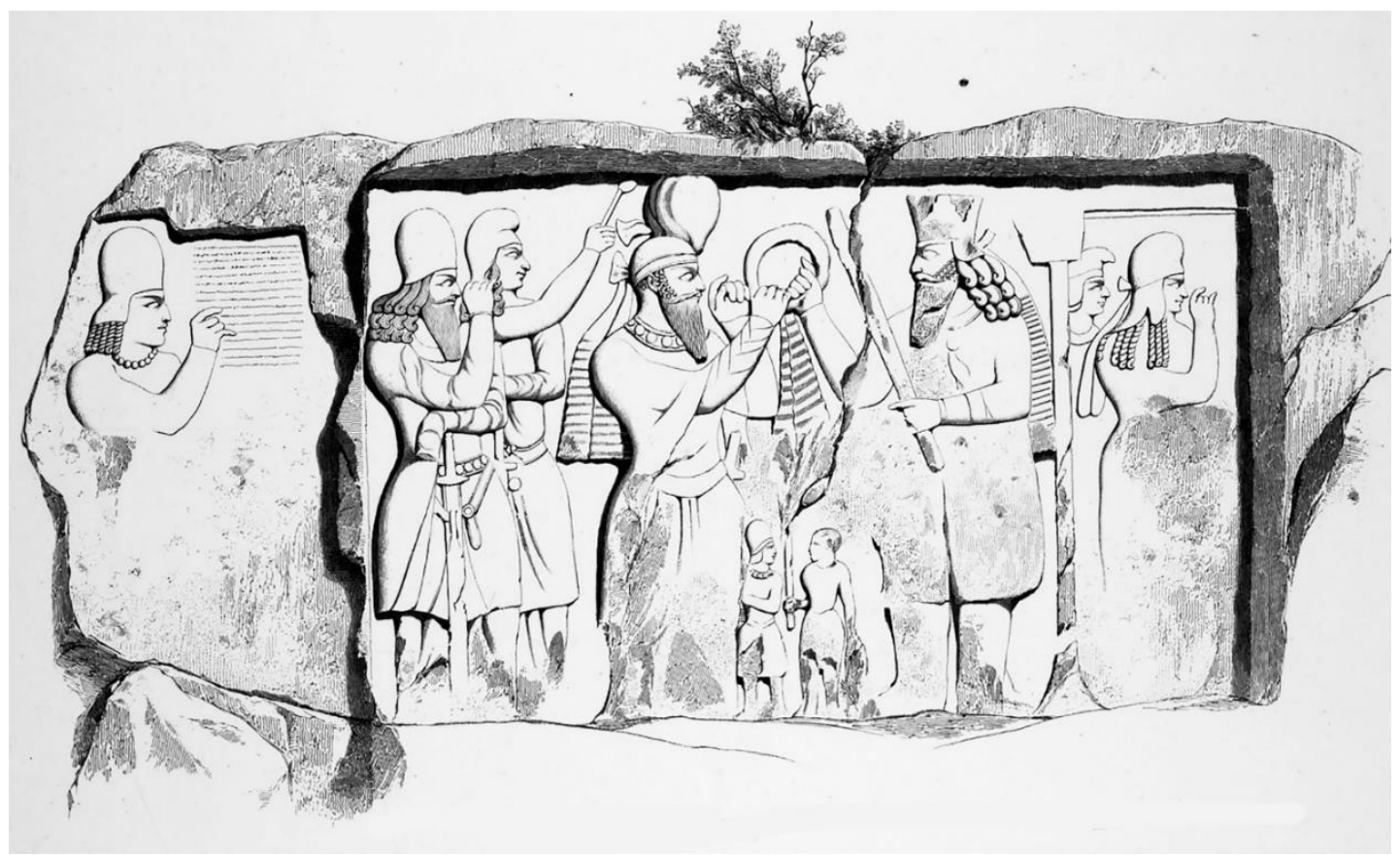

Fig. 1 Ardashir I's investiture relief in Naqsh-e Rajab. Photograph: (C) The New York Public Library. 'Nakch-i-Redjeb. Bas-relief B'. New York Public Library digital collection. Available from URL: http://digitalcollections.nypl.org/items/510d47e2-9025-a3d9-e040-e00a18064a99.

But, looking at the ornaments on the cloaks of the god and the goddess, we meet again, in a highly sophisticated shape, the old Iranian symbols of 5000 years ago. ${ }^{11}$

The themes selected by Ardashir I, divine investiture and victory, remained standard throughout the dynasty. Investiture reliefs were commissioned by his son Shapur I and his grandson Bahram I. It was Ardashir's great grandson, Bahram II who turned his attention from these formal themes to a variety of court and family scenes. ${ }^{12}$ 'Bahram II himself showed a special devotion to his name-deity by naming his son Bahram and choosing the wings of the god's bird as the main element of his crown'. ${ }^{13}$ We see him receiving a foreign delegation at Bishapur, but otherwise reliefs show him with his nobles and his family at Sarab-e Bahram, Naqsh-e Rostam, and fighting a lion at Sar Mashad. The reign of Bahram II saw a weakening of central control and a number of what appear to be different themes of reliefs were carved. ${ }^{14}$

\footnotetext{
${ }^{11}$ Herzfeld 1941, 339.

12 Herrmann \& Curtis 2002.

13 Shahbazi \& Klima 2011.

${ }^{14}$ Herrmann \& Curtis 2002.
} 


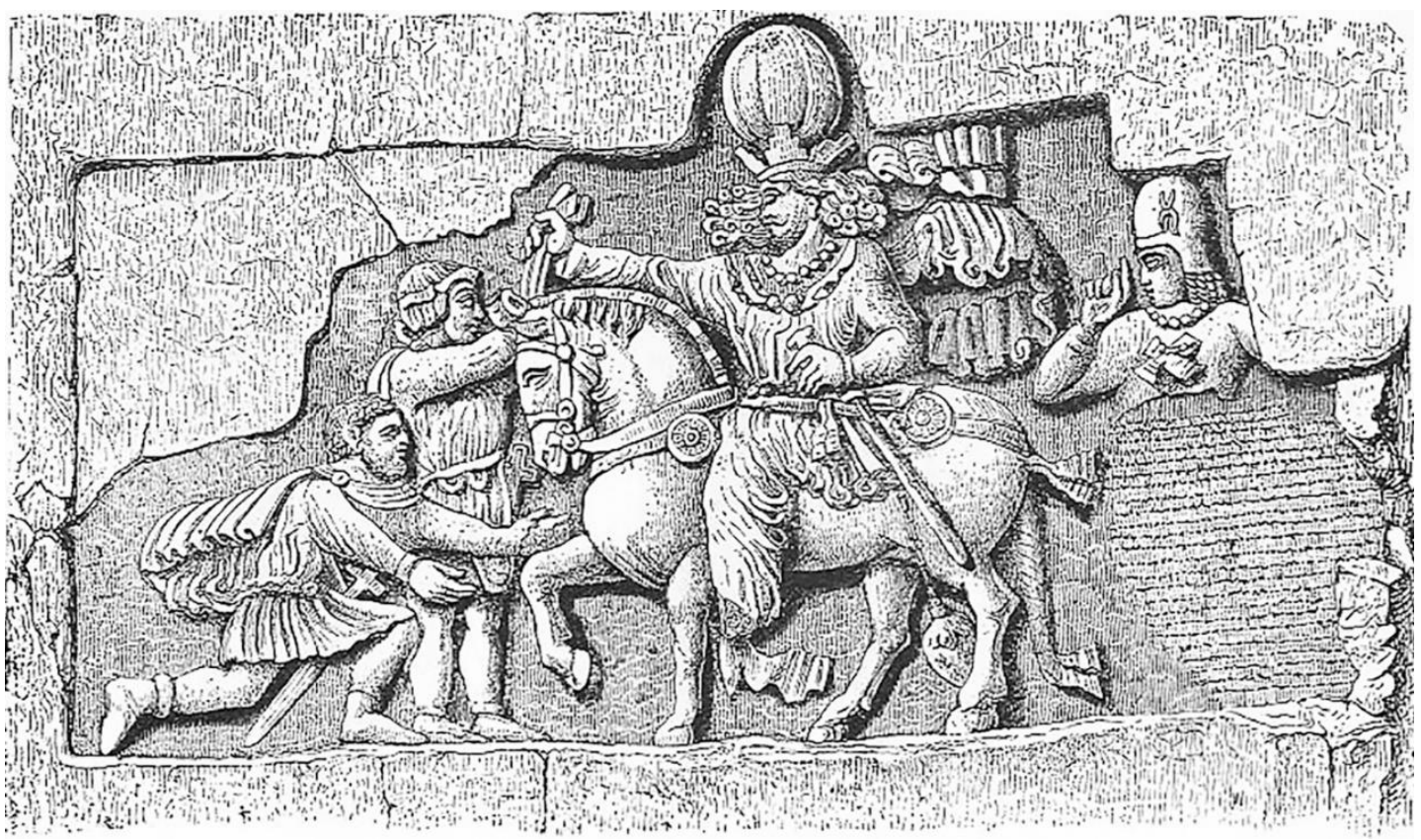

Fig. 2 Relief of Shapur I in Naqsh-e Rostam with Kartir's figure and inscription inside.

Photograph: Rawlinson 1884: The Seven Great Monarchies of the Ancient Eastern World, vol. 3 ch. 27.

The art produced under Bahram II had advanced not only in technique and style but also in subject, abandoning the stereotyped theme of investiture and triumph. ${ }^{15}$ 'As a demonstration of Kartir's exalted status at court and of his considerable influence over Bahram II, Kartir was permitted to have his own portrait and inscription carved on several previously existing rock reliefs'. ${ }^{16}$

\section{Kartir's inscriptions}

Sasanian inscriptions are records sponsored by various rulers of the dynasty, including its founder, concerning their wars, conquests, administration, names of the nobles and lords serving under them, and so forth. The lists of names reveal the social structure and the protocol of the early Sasanian period. Of particular interest are the inscriptions of the chief priest of the early period, Kartir. ${ }^{17}$

Kartir is known from his inscriptions in Fars at Naqsh-e Rajab (KNRb), to the left of the investiture relief of Ardashir (Fig. 1); Naqsh-e Rostam (KNRm), to the right of Shapur I's triumphal relief, behind the horse (Fig. 2); Sar Mashad (KSM), in the province

\footnotetext{
${ }^{15}$ Herrmann 1970, 166.

16 Brosius 2006, 147.

17 Moyne 1974, 27.
} 


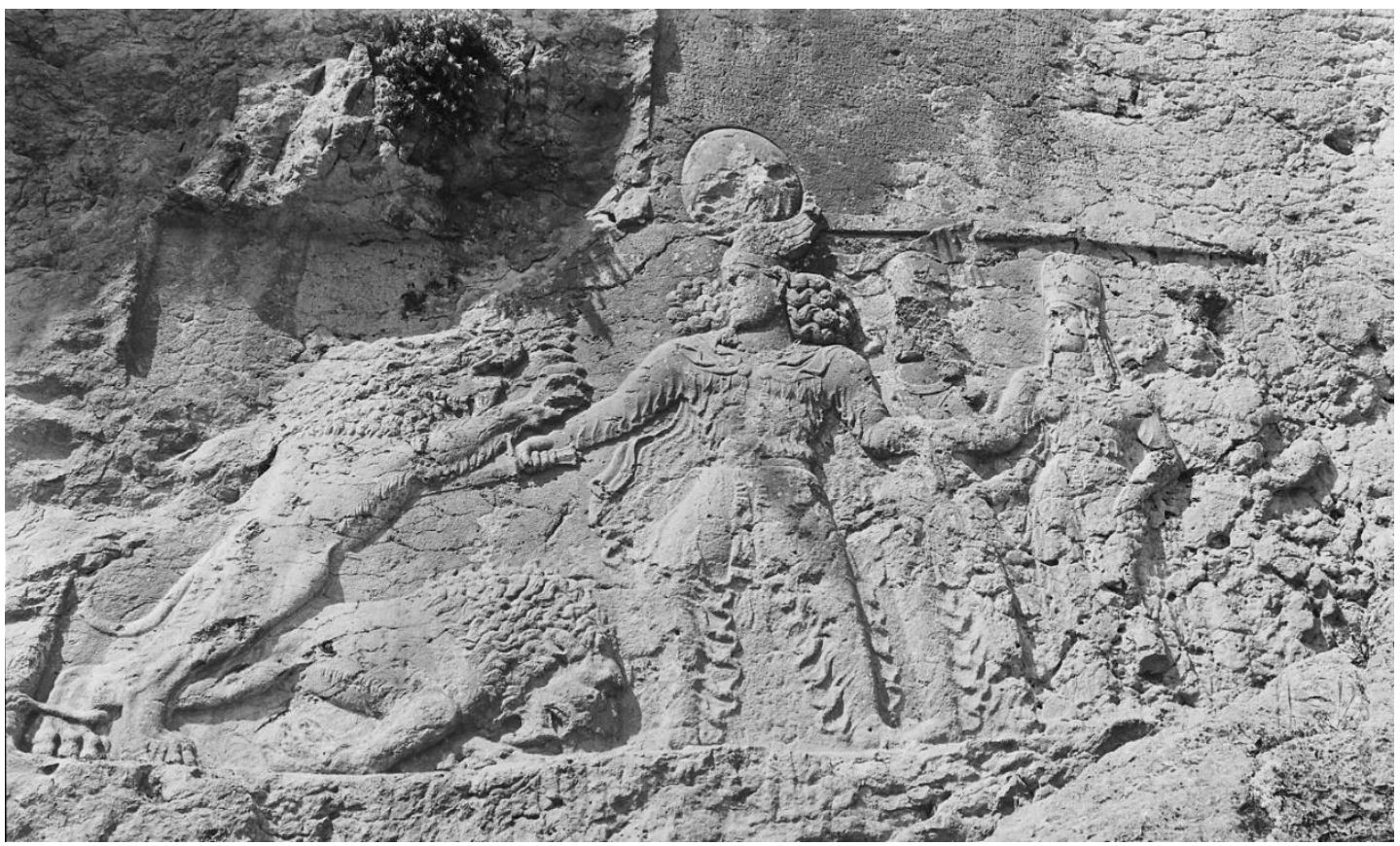

Fig. 3 Sar Mashhad: Sassanid reliefs depicting King Bahram II slaying a lion while making a gesture of protection towards the queen, Kartir and another dignitary. Photograph: (C) Freer Gallery of Art and Arthur M. Sackler Gallery archives.

of Fars, above a relief thematically connected with the inscription (Fig. 3); and below the Middle Persian of Shapur I's triangular (Middle Persian, Partian, Greek; SKZ) inscription on the Kaba-ye Zardosht (KKZ), the tower facing the rock reliefs at Naqsh-e Rostam (Fig. 4). KNRm and the mostly identical KSM contain KKZ, which does not contain the vision narrative, while $\mathrm{KNRb}$ is a summary of the principal ideas in the longer inscriptions. ${ }^{18}$

It is apparent that Kartir really attained a position of prominence and power as early as Ardashir I's time, although he nowhere states this explicitly, merely allowing it to be inferred from the coupling of Ardashir's name with that of Shapur in the first two major statements he makes about himself at KNRm and KSM. This appears to be a later idea of Kartir's old age. KKZ and KNRb are probably earlier than KNRm and KSM. The inscription of Sar Mashad (KSM) is merely a replica of Naqsh-Rostam, probably slightly edited, badly weathered, in some parts less than KNRm. Both are combinations of KKZ and $\mathrm{KNRb}{ }^{19}$

\footnotetext{
${ }^{18}$ Skjærvø 2012.

${ }^{19}$ Sprengling 1953, 38.
} 


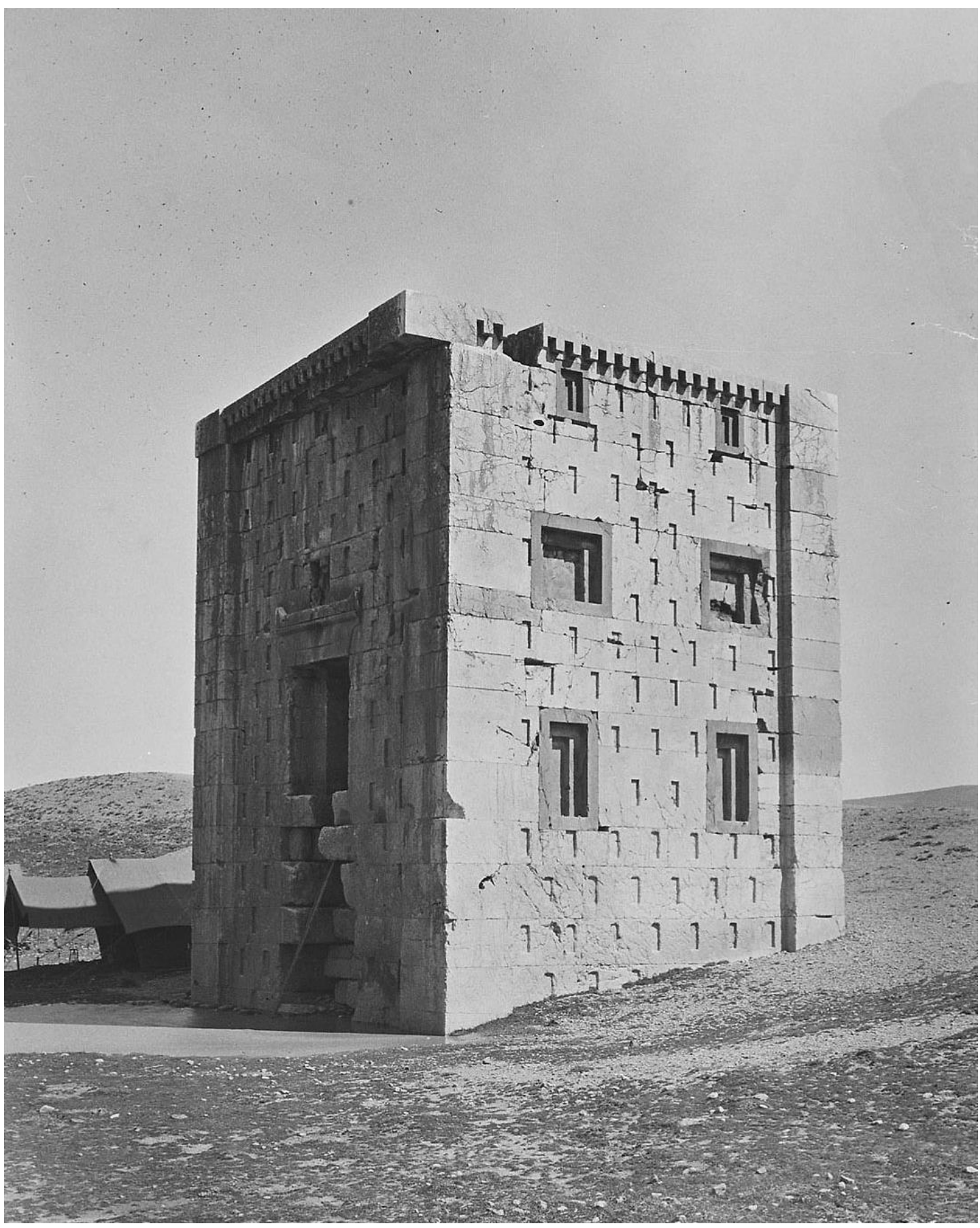

Fig. 4 Naqsh-e Rostam: The tower facing the rock. Photograph: (C) Freer Gallery of Art and Arthur M. Sackler Gallery archives. 
Kartir's inscriptions are the earliest indigenous written testimonies to the basic tenets of Zoroastrianism. They are therefore of the utmost importance for studying the Zoroastrian tradition under the early Sasanians. Focus is on ethics (good or bad behaviour), which, as in other major religions, is encouraged with reference to what awaits the soul after death: rewards for the good, punishment for the wicked. Because of their size and varied language, Kartir's inscriptions are also the most important documents for the knowledge of the early Middle Persian writing system, grammar and vocabulary. Kartir is depicted in his reliefs wearing a tall rounded hat (kuläf) decorated with a scissors-like insignia, a necklace with large pearls and his hand raised with a finger pointing in reverence; he is beardless, indicating that he may have been a eunuch. ${ }^{20}$ Descriptions of some pictorial features of Kartir's new compositions will serve to further demonstrate their unique character.

\section{Naqsh-e Rajab}

Kartir Naqsh-e Rajab is almost certainly the second of the great inscriptions to be carved on Persia's rocks by this remarkable, in some respects great, priest soon after he arrived at the apex of his ambitious career. It is dedicated to the announcement of a new mazdayasnan orthodoxy about the hereafter, the departed, heaven and hell. ${ }^{21}$

Kartir carved his bust figure at Naqsh-e Rajab (Fig. 1, above), with his gesture of respect meaningfully interacting with the older relief of Ardashir I nearby. ${ }^{22}$ The scene $(5 \mathrm{~m} \times 3 \mathrm{~m})$ shows Kartir's bust figure with his pointing finger inserted into the inscription (Fig. 5). In the same relief, six viewers are watching Ohrmazd granting the ring of sovereignty to Ardashir. ${ }^{23}$ The figures are heavy and larger than life-size'. Ardashir and the god Hormazd stand in the middle of the picture; the king receives the crown. His son Shapur, to the left, is witness, participating in the act by raising his right hand in a salute. In a back panel is again the page with the fan. Between the king and the god stand two children; the left one, dressed like the adults, is probably the grandson, later Hormazd I; he salutes the child to the right, who is entirely naked - a unique feature in Sasanian art - and who is surely a Greek divine figure. To the right of the main group, the queen and one lady-in-waiting stand under a canopy. They are turned away as if entirely unconcerned with the ceremony. ${ }^{24}$

\footnotetext{
20 Skjærvø 2012.

${ }^{21}$ Sprengling 1953, 63.

22 Canepa 2010, 586.

${ }^{23}$ Luschey 2011, 379.

${ }^{24}$ Herzfeld 1941, 311.
} 


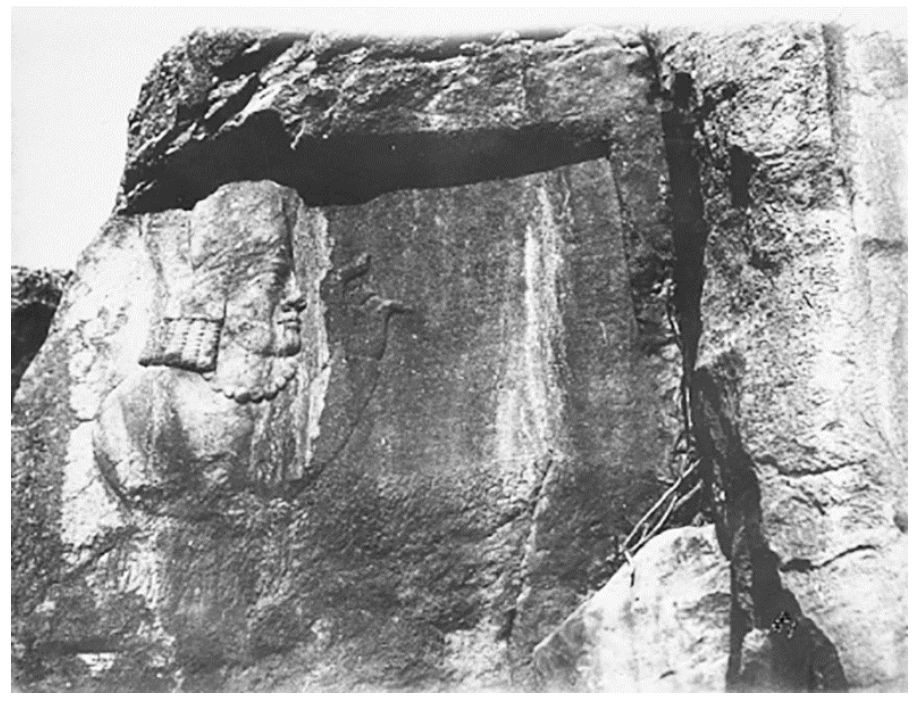

Fig. 5 Naqsh-i Rajab: Sasanian rock relief picturing High Priest Kartir and middle Persian inscription. Photograph: (C) Freer Gallery of Art and Arthur M. Sackler Gallery archives.

Despite the long-time span between Kartir's authority and the reign of Ardashir, Kartir had placed his bas-relief next to Ardashir's so that the canopy on the right and Kartir's rock relief on the left have a line of symmetry through the middle. It is noteworthy that the creation of symmetrical compositions was not foreign to the Sasanians. ${ }^{25}$

\section{Naqsh-e Rostam}

Shapur I carved a rock relief in the centre of the four Achaemenid tombs, in the space underneath the tomb of Darius I. His relief is decidedly triumphal (Fig. 2, above). It clearly commemorates his capture of the Roman emperor Valerian (253-260 CE) and the supposed submission of Philip the Arab. ${ }^{26}$ 'Shapur I can be identified by his mural crown sitting on horseback facing left his outstretched right hand grasps the raised hand of a figure in Roman dress standing in front of his horse. In the foreground and further back another Roman in a half-kneeling position stretches out his hands in supplication towards the king'. ${ }^{27}$ The high priest Kartir, who owed the start of his career to Shapur I, integrated his relief into that of the King of Kings. The relief is a bust image of Kartir carved to the right of Shapur I's main relief, portraying the priest raising his hand in a gesture of respect directed at the king. ${ }^{28}$

\footnotetext{
25 Godard 1965, 212.

26 Canepa 2010, 579.

27 Macdermot 1954, 77.

${ }^{28}$ Canepa 2010, 586.
} 
Kartir's inscription carved just below his bust figure, behind Shapur I's horse, is unsurpassed for the elegance of its script, which is a real pleasure to the eye. ${ }^{29}$ The king's crown marks the top of the rock relief, while Kartir's inscription is located at the middle of that, filling the space behind the tail of Shapur's horse, and the base of his bust figure. There needed to be a strong connection between the inscription and Kartir's figure to prevent the inscription from being connected to the king instead, who is naturally the most important figure in the relief. Here, Kartir's figure could not be larger than Shapur I's but it was necessary to engrave the inscription in a certain size lettering to be readable on the rock. It is probably for that reason that the inscription's frame was allowed to go outside of the right edge of the main relief.

\section{Sar Mashad}

Kartir enjoyed, and benefited from, the support and approval of Bahram II, who not only authorized him to have inscriptions carved and decorated with his bust, but even had him included among the royal family and court officials on several reliefs like Sar Mashad. ${ }^{30}$

The monumental cliff carving of the Sasanian king Bahram II is near the mountain village of Sar Mashad. This consists of a large bas-relief of the king and his court, and an 800 -word inscription in middle Persian, the second longest yet discovered in Persia. The inscription originally had 59 lines, not one of which is completely legible today. It is approximately $5.28 \mathrm{~m}$ long and $2.76 \mathrm{~m}$ high. The letters of the inscription are $3.5 \mathrm{~cm}$ high. The first fourteen lines are a copy of the inscription of Kartir at Naqsh-Rostam. Lines 53 to 59 are a copy of the inscription at Naqsh-e Rajab. The bas-relief underneath is $4.65 \mathrm{~m}$ long and $2.14 \mathrm{~m}$ high. Part of the rock relief, $2.6 \mathrm{~m}$ long, is under the left side of the inscription. $^{31}$

The rock relief depicts Bahram II as a hunter who has killed a lion and is dispatching a second one with his sword (Fig. 3, above); he holds the right hand of his queen in a gesture of protection while Kartir and a courtier are behind him. ${ }^{32}$ In Bahram II's proud stance, and in the defeat of the lion, he has achieved an impressive composition to which little is added by the much damaged group of three figures on the right. For the first time since Ardashir discovered the effectiveness of the equestrian pose, Ardashir's remarkable rock relief at Naqsh-Rostam, the monarch is shown on his feet. The easy dominance which had been achieved by having the king mounted while his attendants followed on foot is here attained by returning to the archaic convention (also used by Ardashir in his early reliefs like Firuzabad) of making the king taller than his companions. Bahram II is given additional emphasis by being placed in the centre of this dramatic scene. He is

\footnotetext{
${ }^{29}$ Nyberg 1960, 46.

${ }^{30}$ Gignoux \& Litvinsky 1996, 402.

${ }^{31}$ Frye 1949a, 188-189.

32 Shahbazi \& Klima 2011.
} 
represented frontally, except for his head, which is turned in the direction of the lion he is slaying: his expression is calm, he barely glances at the ferocious beast springing at his right arm. His diadem ties fly out behind and are also rendered in a much freer and less stylized manner. His cloak gently billows under his right arm instead of flying out in formal curves. Kartir's kulaf is adorned with his scissors-like device although he has not yet been awarded the diadem and ties that adorn his hat at Naqsh-e Rostam. ${ }^{33}$ Comparing Kartir's visionary journey narration in the context of his social and political life with the surrealism movement of the early twentieth century reveals his surreal approach.

\section{Surrealism}

The word 'surrealism' is a neologism invented around 1917 by Guillaume Apollinaire, who had in mind, when he coined the word, the poetic fact itself. Soon after his death in 1918, the term was current in avant-garde circles, but with a rather nebulous meaning, not connected with any particular tendency or theory. It was André Breton who finally took hold of the word and defined it in the first Manifesto of Surrealism in 1924 as "pure psychic automatism' - a dictation of the mind, a written poetry obtained without any intervention of conscious thought. ${ }^{34}$

Breton, believing logical methods to be applicable only to solving problems of secondary interests, states that:

By pure chance that our mental world which we pretended not to be concerned with any longer- and, in my opinion by far the most important part- has been brought back to light. For this we must give thanks to the discoveries of Sigmund Freud. On the basis of these discoveries a current of opinion is finally forming by means of which the human explorer will be able to carry his investigations much further, authorized as he will henceforth be not to confine himself solely to the most summary realities. ${ }^{35}$

Surrealism drew upon Freudian speculation to free the artist from the formalism of the traditional subject matter and the traditional canons of visualization. It was indeed the expression of joy of the self-freed from the restriction of the rational. Surrealists looked for symbols to express their new thoughts and found meaningful ones in Freudianism. ${ }^{36}$

\footnotetext{
${ }^{33}$ Herrmann 1970, 167.

34 Jean 1975, 7.

35 Breton 1969, 10.

${ }^{36}$ Dedrick 1975, 1.
} 
This hardly alluded to painting. In fact, strong doubts soon arose among the newly-named surrealist group about the possibility of adapting the principles of automatism, which rule out retouching, to painting. One year after the manifesto, Breton, in his first series of articles, which were called Surrealism and Painting, attempted to show how the work of certain painters could be related to surrealism. ${ }^{37}$

Breton defines surrealism as Psychic automatism in its pure state, by which one proposes to express - verbally, by means of the written word, or in any other manner - the actual functioning of thought. Dictated by thought, in the absence of any control exercised by reason, exempt from any aesthetic or moral concern. And from the view of philosophy, surrealism is based on the belief in the superior reality of certain forms of previously neglected associations, in the omnipotence of dream, in the disinterested play of thought, while it tends to solve all the principal problems of life. ${ }^{38}$ Breton's declarations and the numerous political views pronounced by the surrealists during the war in Morocco marked a turning point in their thinking and awareness of the Orient, which partially explains the central place that the Orient occupies in the surrealist imagination. Presuming that one subscribes to Breton's idea, the Orient would appear to be a true catalyst of the surrealist movement as well as an essential driving force and source of inspiration. There was an indisputable presence of an Oriental leitmotif in surrealism, of which Breton's Nadja would be the prototype: the text repeatedly overlaps with $A$ Thousand and One Nights through its recourse to the theme of wandering, the dream, the woman being the initiator and the fortuitous meeting. ${ }^{39}$

We find much in the medieval literature that foreshadows what develops later into notions of the real and surreal in art. A paradigm of the medieval dream vision genre which we might recognize now as surrealism is The Kingis Quair, a fifteenth-century poem long attributed to James I, who was the king of Scotland. In this poem James I creates a world in which his narrator escapes from the confining, isolated everyday reality of a prison tower into a dream of movement and dialogue. ${ }^{40}$ Consequently, surrealism already has roots in the past that are older than the first manifesto of surrealism. To define Kartir's rock reliefs as another example of former surreal experience it is necessary to pay close attention to his visionary journey, which reveals the surreal aspect of his story.

\section{Kartir's journey}

The longer inscriptions of Kartir are divided into four sections: a description of Kartir's career under the four kings, ending with the summary of his title; a continuation of the account of his achievements under Bahram II, reflections on his life achievements as an

\footnotetext{
${ }^{37}$ Jean $1975,8$.

38 Breton 1969, 26.

${ }^{39}$ Antle 2006, 4-5.

${ }^{40}$ Hodapp 2009, 55.
} 
introduction to the account of the heavenly journey; the vision narrative (only KNRm, KSM); and results of the heavenly journey and conclusion. ${ }^{41}$

One can never cease wondering what motives may have inspired the high priest to choose such places for proclaiming his grand achievements and honours. Perhaps the explanation is to be found in the last part of the inscription, which describes the mighty vision from beyond by which Kartir attained assurance as to the fundamental religious question. Naqsh-e Rostam was the ancient burial place of the Achaemeniden kings. ${ }^{42}$ Naqsh-e Rajab was possibly the place of crowning for the Sasanian kings. Richard N. Frye cites the importance of Sar Mashad; Ghirshman, on the other hand, suggested, in a conversation, that Sasanian bas-reliefs and inscriptions are found near caves, either natural or man-made, and that these caves are probably the tombs of Sasanian monarchs or high dignitaries. Sar Mashad does not prove the exception, for there is a cave in the mountain above the bas-relief. It is possible that this was the grave of Bahram II, or of Kartir himself. The numerous ruins in the vicinity of Sar Mashad do testify to the existence of a city there in Sasanian times. Perhaps it was the native town of Kartir which persuaded him to carve his inscription on the mountain nearby. ${ }^{43}$ These places, being wild and gloomy, would seem to be proper places for supernatural revelation. ${ }^{44}$ According to the Kartir's inscription, his journey had occurred at the time of Shapur I, as he states:

After I had asked the gods for help in the manner it is written in this inscription, then, [at the time] of Shapur, king of kings, I made a séance for the sake of the gods and my own soul: may I prove to be good! But if I do prove to be bad, then may I take this faith in you, gods! And I also insisted that: If I prove to be good, then, do you gods show me now how it is in the beyond with those who are good, and so I will hold on to this faith in you, gods! And if I prove to be bad, then, do you gods show me now how it is in the beyond with those who are bad, and so I will hold firmly on to this faith which I receive from you, gods, for all time! $!^{45}$

\footnotetext{
41 Skjærvø 2012.

42 Nyberg 1960, 45.

${ }^{43}$ Frye $1949 b, 70$.

${ }^{44}$ Nyberg 1960, 45.

45 Skjærvø 2008, 171.
} 
Then the journey itself starts in the midst of the story with an utterance by someone (third person's perspective). Agreement about the identity of the narrators has not been achieved. Their job is to report what they see. Only once do they actively take part in the story, when they are afraid to cross the bridge. The characters they see and the connected events include the following: A prince the colour of dawn appears mounted on a fine horse and holding a banner. A person of the same form as Kartir, Kartir's likeness, appears. Then a splendid woman appears, coming from the east on a very luminous road. They meet and greet one another (bowing and clasping hands) and then walk back the way she came. She is in front, he behind. A prince the colour of dawn appears with a pair of scales before him, on which he weighs something, whom they pass. Another prince the colour of dawn appears, more magnificent than the ones they saw at first, holding a ladle (used for placing firewood on the fire) in his hand that then appears like a bottomless well full of evil animals, over which a piece of wood lies like a bridge; the bridge now becomes greater in width than in length. The narrators are dismayed at the sight of hell, but are told not to worry and just keep reporting.

As the woman and Kartir's likeness prepare to cross the bridge, a prince the colour of dawn, more magnificent than the ones they saw at first, appears from the other side and crosses the bridge. The prince takes the hand of Kartir's likeness and leads him across, walking in front, while the woman is behind, bringing up the rear. They keep walking upwards to a palace or vaulted porch, before which golden thrones stand with festive meals. They then keep going up to the heights. The woman leads Kartir's likeness past two more palaces, this time preceding him. There is a possible mention of a ladder here. There is a final mention of the woman, and someone (Kartir's likeness?) sits down in the window of divine Bahram, while someone else brings Kartir's likeness bread, meat and wine. A last prince keeps pointing and smiling at Kartir's likeness, who bows to him in reverence. The prince, mounted on a horse and holding a banner, may be divine Bahram [Verethragna], who, in the Bundahishn, is called the one who carries the banner of the gods for their victory. The fourth prince, who crosses the bridge to take them safely across, may again be deity Bahram, who together with other deities stands at the bridge in the account of Zoroastrian sacred texts. Thus, it is quite likely that Bahram the king represents a divine Bahram, and so there is perfect agreement between the narrative and the relief.

In the relief at Sar Mashad (Fig. 3, above) we see Bahram II (recognizable by his winged crown) in the process of killing a lion, and behind him, Kartir (recognizable by his shears), then the queen and a fourth person (much damaged), who could be the crown prince. ${ }^{46}$ The Zoroastrians regarded lions as one of the highest manifestations of Evil, therefore, the lion-hunt of Bahram II on this relief may have symbolized the struggle

46 Skjærvø 2012. 
between Good (the king) and Evil (the lion). A so-called shoulder ornament, or hair whorl, is sculpted around the neck area of the jumping lion, while the other lion, lacks it, demonstrating that two different lions are depicted. ${ }^{47}$

Mainly on the grounds of the uniqueness of such an illustration in Sasanian art and the fact that the characters in the relief are Bahram II and his queen, the designer of the relief may well have chosen the royal family as models for the otherworldly characters portrayed in the inscription and the common motif of the hunt to illustrate the battle with the wild animals guarding the bridge. If the relief is not thematically related to the inscription, but simply another hunting scene, it is not obvious what the roles of the queen and the chief priest, Kartir, would be. It also does not explain why Kartir is portrayed between the king and the queen, which is different from the other reliefs of Bahram II. Moreover, the queen's hand is not formally raised, but clutched by the king, apparently to protect her and Kartir. It is notable that the Sasanian kings are commonly depicted on horse in hunting scenes on bowls, while hunting youths on foot are seen on vases. ${ }^{48}$ All these reinforce the idea that the Sar Mashad rock relief is not an official ritual depiction but an illustration of Kartir's inscription carved above it.

\section{Shamanistic traits of Kartir's journey}

The word Shaman itself appears to be connected with the Zoroastrian tradition. Not only is the word clearly present in Zoroastrian tradition, but also the concept of Shamanistic voyage to the netherworld, and the Zoroastrian literature contains this fact as well. ${ }^{49} \mathrm{We}$ can define shamanism as a symbolic means of addressing psychological and social conflict because shamanic performances always aim to control or remedy specific problems, or bring about a transformation of reality that improves upon existing conditions. The emotionally compelling aspect of shamanism is its dramatization of the distress experienced by the shaman's patrons. Through these dramatizations, shamans can direct the feelings of their patrons and often resolve social tension. The shaman helps his patrons appreciate symbols that address, interpret and contribute to the resolution of their most troubling problems and conflicts by manifesting in his own body symbols that represent the resolution of problems besetting his patrons. ${ }^{50}$

The first type of shamanistic voyage in the Zoroastrian tradition was made to gain knowledge of the future and was apocalyptic and eschatological in nature. The second type was geared toward discovering the truth about the religion, correctly performing the rites and rituals, and finally visiting heaven and hell. By accomplishing either or both of these types of voyages, the messenger was able to come back to earth and inform the co-

47 Tanabe 1990, 32.

48 Skjærvø 2012.

${ }^{49}$ Daryaee 2000, 31.

50 Porterfield 1987, 725 . 
religionists as well as the non-believers of what was to come and how to act so that they would not end up in the pits of hell. These ideas certainly predated Zoroaster. ${ }^{51}$

The apocalyptic and vision genre of Middle Persian literature is the most imaginative and interesting of the Middle Persian corpus. These texts predict the way in which the world will come to an end and the fate of the people and of Iranshahr, the empire of the Sasanians. ${ }^{52}$ Thus, the visionary narrative of Kartir is not unique and parallels are found in Middle Persian. Zoroaster himself did not have a part in the pagan reintroduction of vision and journey into the afterlife, but now it was assigned to him and his adherents. In an apocalyptic text in Middle Persian (Zand I Wahman Yasn) it is stated that Zoroaster was given the 'all-knowing wisdom' in the form of water poured onto his hands to drink, which induced a deep sleep for seven days and nights. By doing this Zoroaster was able to see the future and what would come to be, how the end of the world would appear and, finally, the victory of righteousness over evil. ${ }^{53}$

In the Denkard, King Wishtasp is depicted as hesitating to join the new religion. After drinking mang (and thus making an extra-terrestrial journey), his doubts are resolved. Arda Wiraz is the principal character of the Zoroastrian Middle Persian text, Arda Wiraz Namag. It is a report of Wiraz's extra-terrestrial soul journey, including a description of heaven and hell. Wiraz was chosen because of his virtue, and after he drank the narcotic mang he was unconscious for seven days and nights. When Wiraz's soul returns to his body, he narrates his experiences. Wiraz was sent in order to verify Zoroastrian beliefs about the invisible world, and the efficacy of the rituals of the Zoroastrian community. This scene of piety, troubled by religious uncertainty, seems to be set some time after the fall of the Achaemenid empire, but the final redaction of the text probably refers to the early Islamic period. Inevitably, this work has been compared with Dante's Divine Comedy ${ }^{54}$ which was regarded by Breton as the starting point for when a number of poets could pass for surrealists. ${ }^{55}$

In the case of Kartir, it is again a matter of a vision of heaven and hell in the course of a soul-journey. He explains in the Naqsh-e Rajab inscription that he was seeking assurance that the cult, to whose development he had contributed, was efficacious. Thus, again, the theme of doubt is implied in a piece of visionary literature. ${ }^{56}$

The doctrine expounded by Kartir, which did not even refer to Zoroaster, was also essentially eschatological and could be summed up in a few simple ideas, such as the existence of a paradise for the righteous and a hell for the wicked. The need is stressed

\footnotetext{
51 Daryaee 2000, 31.

52 Daryaee 2009, 111.

${ }^{53}$ Daryaee 2000, 33.

${ }^{54}$ Gignoux 2011.

55 Breton 1969, 26.

56 Gignoux 2011.
} 
for justice and for obedience to the kings and the gods. Among the latter, explicit mention is made of Ohrmazd. In the account of a vision granted to Kartir by the gods, several deities with an eschatological function appear, though are not named. This kind of journey into the other world, although presented for the purpose of moral edification, and as a warning for the faithful, suggests a shamanistic experience. ${ }^{57}$ Although Kartir doesn't mention how he had gone on the journey up to another world, it is most likely that he drank some kind of liquid to fall into a deep sleep for his heavenly journey. ${ }^{58}$

The Shaman often goes into a trance to embody the spirits and their demands. In the emergency situation that typically called for shamanistic performance, trances enabled shamans to convey the demands of the spirits and dramatize the human pain, fear and anger out of which those demands arose. ${ }^{59}$ This function of shamans can provide an interpretation as to who the narrators in Kartir's journey might be. In Kartir's mind they may have been the embodied spirits speaking from the beyond. Notice that Kartir's inscriptions are directly narrated by him and they are not redactions assembled centuries later.

\section{Kartir's surreal approach}

The history of surrealism evolves out of the fact that individuals at that time were comfortable in their own skins and listened to their inner selves. They were a part of their society responding to all of the push and shove, all of the high tragedy and madness of their universe, as it was about to dissolve in war. They were concerned about the madness of the social institution that justified the noble death, war and the sacrifice of the self for political ends. ${ }^{60}$

After World War I, reality was no longer a given, nor was it a natural, familiar environment. The self, cut loose from its attachments, had to discover meaning where possible. After Europe's collapse into barbarism and the manifest bankruptcy of the ideology of progress, after a deep fissure had opened between the experience of the trenches and the official language of heroism and victory, after the romantic rhetorical conventions of the nineteenth century had proved themselves incapable of representing the reality of the war, the world was permanently surrealist. ${ }^{61}$ In these circumstances the Surrealists looked for symbols to express their new thoughts, and found meaningful ones in Freudianism. ${ }^{62}$

57 Gignoux \& Litvinsky 1996, 404.

58 Daryaee 2001, 4.

${ }^{59}$ Porterfield 1987, 728.

${ }^{60}$ Dedrick 1975, 2.

${ }^{61}$ Clifford 1981, 541.

${ }^{62}$ Dedrick 1975, 2. 
They made the mind a seat of literary and artistic wonders. They set out to explore the mind and especially its subliminal states. In the first instance, subliminal states were explored as a means towards a more imaginative approach to literature, but soon these were extended to the visual arts. Eventually, despite surrealism being currently known predominantly as a visual arts movement, it transcended the arts and was intended to be a philosophy of life, or lifestyle as it would perhaps be expressed today, informed by a political agenda and geared towards revolution. ${ }^{63}$

The following clarifies similarities between Kartir's time and what surrealists of the twentieth century had to deal with on the ground in terms of social and political conditions. At the close of Shapur I's reign, when Kartir performed his visionary journey, the country was involved in wars in Mesopotamia, Syria and Armenia against Romans or Parthian family, and although Shapur I took a large part of that territory from the Romans, ${ }^{64}$ these wars surely came at a high cost to the people living in Persia in the third century. Moreover, the Roman prisoners, who contributed to establishing Roman-style construction, were settled in the Sasanian realm, ${ }^{65}$ which must have caused various cultural and religious challenges. As mentioned previously, Bahram I, the eldest son of Shapur I, had been passed over by him, and Shapur I had selected his younger son Hormizd I as his immediate heir to the throne, and had invested him during his lifetime. A year later, Bahram I succeeded Hormizd I; this means that it is likely there would have been animosity and conflict among the nobles at that time.

From this perspective, the rise of surrealism in the early twentieth century in its quest for superior meaning is comparable to what Kartir cites about the aim of his heavenly journey. Kartir's journey up to paradise was undertaken to regain confidence in the correctness of his ritual practices in a time of doubt. Kartir's experience is summarized in the inscription at Naqsh-e Rajab, where he explains how he implored the gods for a sign to make him confident that paradise and hell exist and are the final abodes of the good and the bad, respectively. Moreover, the inscription was written not only so that those who read it would likewise be more confident that the current religious beliefs and practices were correct, but also for fame and prosperity to come to their bodies and 'righteousness' to their souls in this world, as happened to Kartir. In the introduction to the vision narrative, Kartir stressed the need for greater confidence in his religious beliefs, but also adduces his long service to the gods as a reason why they should show him what happens to the souls after death, and thus confirm the correctness of his deeds. ${ }^{66}$ He then narrates his visionary journey.

\footnotetext{
${ }^{63}$ Bauduin 2014, 10.

${ }^{64}$ Daryaee 2009, 4.

${ }^{65}$ Garthwaite 2005, 91.

66 Skjærvø 2012.
} 
As previously stated, the definition of surrealism in literary circles was extended to the realm of visual arts. Here, after explaining the visionary aspects of Kartir's inscriptions, the aim is to indicate some surreal features in Kartir's rock reliefs, which were carved years after his visionary experience. From this perspective, what is noteworthy is Kartir's practice of adding his bust and inscription to the previous rock reliefs. They are completely different from, for example, the busts carved on the rock relief, which show Shapur I and his followers in Naqsh-e Rajab, ${ }^{67}$ where Shapur I is represented on horseback with a large retinue on foot. The followers are drawn in a kind of disappearing perspective in several rows, layered behind each other. These figures diminish in height, but not in breadth of shoulders; if the lower parts of the bodies did not disappear behind the figures in the foreground, they would be dwarfed (Fig. 6). ${ }^{68}$ While there was enough space for Kartir to be depicted as a full figure, he is always seen in bust form in the older Sasanian rock reliefs where he appears with his inscription. They seem to be intentionally carved to produce a strange and unfamiliar impression on the viewer.

It is important to note that the surrealists were intensely interested in unusual worlds. 'Their attitude was to render the unfamiliar comprehensible by making the familiar strange. The contrast is, in fact, generated by a continuous play of the familiar and the strange. ${ }^{69}$ In Breton's opinion the marvelous is always beautiful and in the realm of literature, only the marvelous is capable of enriching works such as the novel, and generally anything that involves storytelling. He then adds, the marvelous is not the same in every period of history. It partakes in some obscure way of a sort of general revelation only the fragments of which come down to us like any symbol capable of affecting the human sensibility for a period of time. ${ }^{70}$

Inserting a bust into the composition to make an unfamiliar space, or a familiar space unfamiliar, was effectively done by the Italian artist Giorgio de Chirico (1888-1978). He is known as an initiator of surrealism. ${ }^{71}$ De Chirico was one of the most notable twentieth-century artists. He embarked on a series of paintings which he termed Metaphysical. In his artwork unexpected combinations and dispositions of objects offer a challenge to the order of logic. Architecture and object carry symbolic meanings and address questions of space, time and identity. ${ }^{72}$

The realm of visual art that was most influenced by surrealism was painting, and it might not seem convincing to extend it, in its early form, to sculpture. According to Ernst Herzfeld, it is most important to note that from the beginning of Sasanian art

67 Herrmann \& Curtis 2002.

${ }^{68}$ Herzfeld 1941, 314.

${ }^{69}$ Clifford 1981, 542.

${ }^{70}$ Breton 1969, 14-16.

71 Jean 1975, 8.

72 Barrow 2005, 345. 


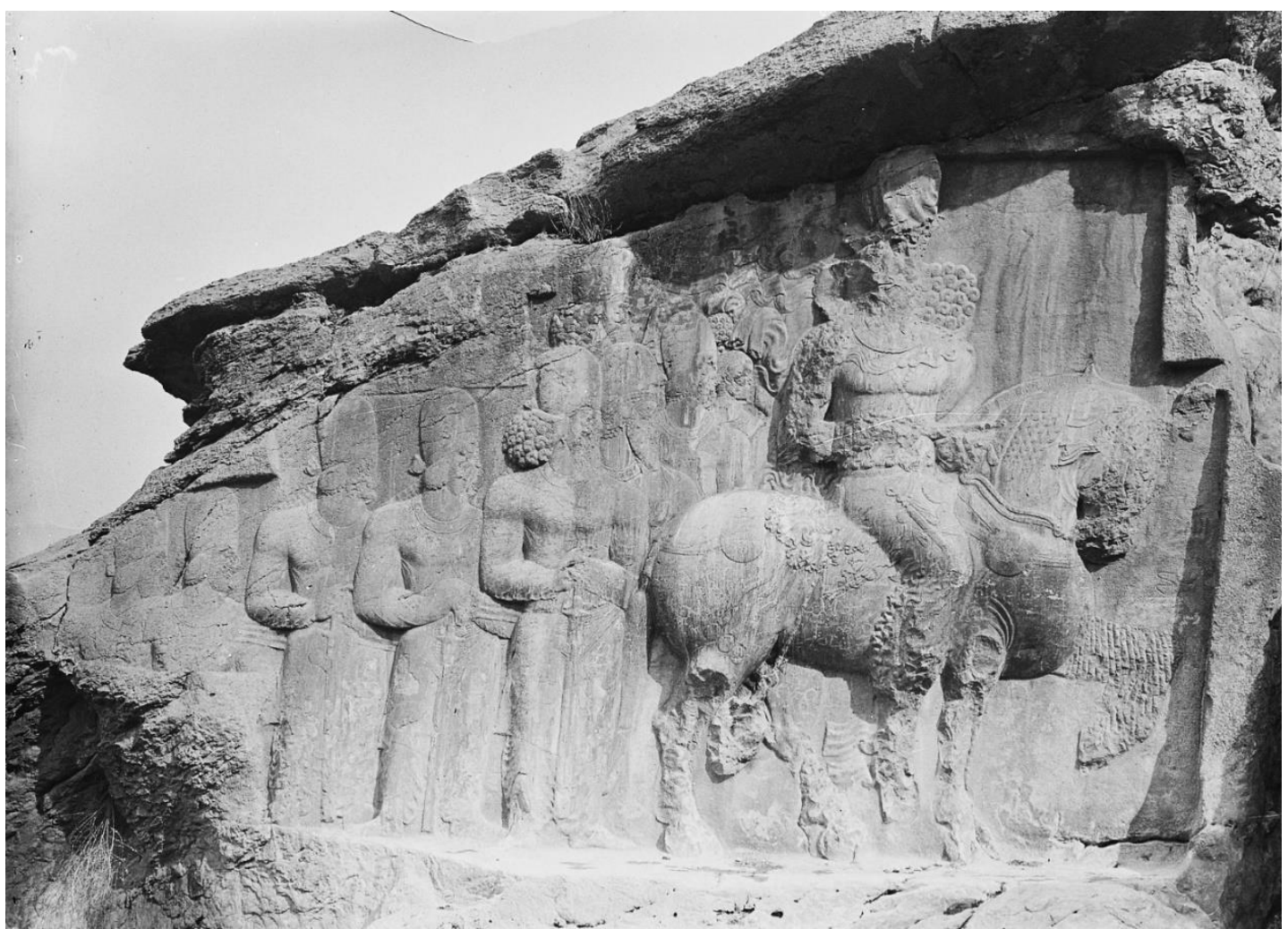

Fig. 6 Naqsh-i Rajab: Sassanid rock reliefs picturing Shapur I, mounted, with retinue on foot. Photograph: (C) Freer Gallery of Art and Arthur M. Sackler Gallery archives.

painting was the branch in which the motifs and the stylistic details of sculpture were developed. The rock-sculptures, then, are to be judged like paintings which were exceptionally executed in relief on rocks, rather than in colour on a wall. ${ }^{73}$ As a result, it is likely that Kartir's aim in depicting his bust when he added his figure to the existing rock reliefs was not to present his actual figure but his likeness, as he had mentioned in his narration, to increase the impression of a newly made composition in order to stress the imaginary quality of his spiritual journey by making an unfamiliar space. It is remarkable that Kartir's bust is always connected with his inscription as if the inscription were giving permission to Kartir to add his figure to the previous rock reliefs and not his grand status within the court, as no other Sasanian kings used the rock reliefs of their ancestors to carve a relief of themselves.

\footnotetext{
${ }^{73}$ Herzfeld 1941, 339.
} 
Lévi Strauss provides an explanation of the shamanistic performance which was undertaken to facilitate difficult childbirth. The sick woman suffers because she has lost her spiritual double or, more correctly, one of the specific doubles which together constitute her vital strength. The shaman, assisted by his tutelary spirits, undertakes a journey to the supernatural world in order to snatch the double from the malevolent spirit who has captured it by restoring it to its owner, and she achieves the cure. This interpretation is based on the concept of purba. The purba and the niga are two different spiritual principles. Unlike the purba, the niga cannot be stolen from its possessor, and only human beings and animals own one. A plant or a stone has a purba but not a niga. The same is true of a corpse; and in a child, the niga only develops with age. It seems, therefore, that one could, without too much inaccuracy, interpret niga as 'vital strength', and purba as 'double' or 'soul' ${ }^{74}$ Consequently, regarding the importance of the double or likeness in the shamanistic journey, the double or likeness should have been a most important matter for Kartir, a motif indicating his visionary experience on his rock reliefs.

Bahram II's rock relief in Naqsh-e Rostam, where the bust figures appear again, strengthens this view (Fig. 7). The site had some sort of importance in the Elamite era but was transformed by Darius to serve as the main royal necropolis for the Achaemenid dynasty. The Achaemenids and the Sasanians both carved more rock reliefs at Naqsh-e Rostam than at any other site in the province or empire. The wealth of sculptural, architectural and inscriptional features from these two temporally disparate dynasties suggests that it served as a ritual and symbolic centre. The main constituents of Naqsh-e Rostam are traces of Elamite reliefs, four Achaemenid funerary reliefs, one mysterious Achaemenid tower, known as the Kaaba-ye Zardosht and eight completed Sasanian basrelief sculptures. ${ }^{75}$

By the Sasanian period it is difficult to discern elements of distinctive Elamite identity in southwestern Iran, although there are some indications that the Elamite language survived in places, from the Babylonian Talmud and the tenth-century writers al-Istakhri and Ibn Hawqal. ${ }^{76}$ The incredible linguistic and ritual parallels between the content of the inscriptions of Shapur I and the Achaemenidens suggest that the Sasanians valued and drew on a deep cultural well of Persian traditions, even if they did not fully understand the exact history of their ultimate source. The final two-fifths of Shapur I's Kaaba-ye Zardosht inscription describes a complex ritual protocol. Not only did Shapur

I physically anchor his protocol on the Achaemenid tower, but he constructed the ritual itself with inspiration from ancient Persian royal traditions. Much like the

\footnotetext{
${ }^{74}$ Levi-Strauss 1963, 188-189.

75 Canepa 2010, 575.

76 Potts 2004, 410.
} 

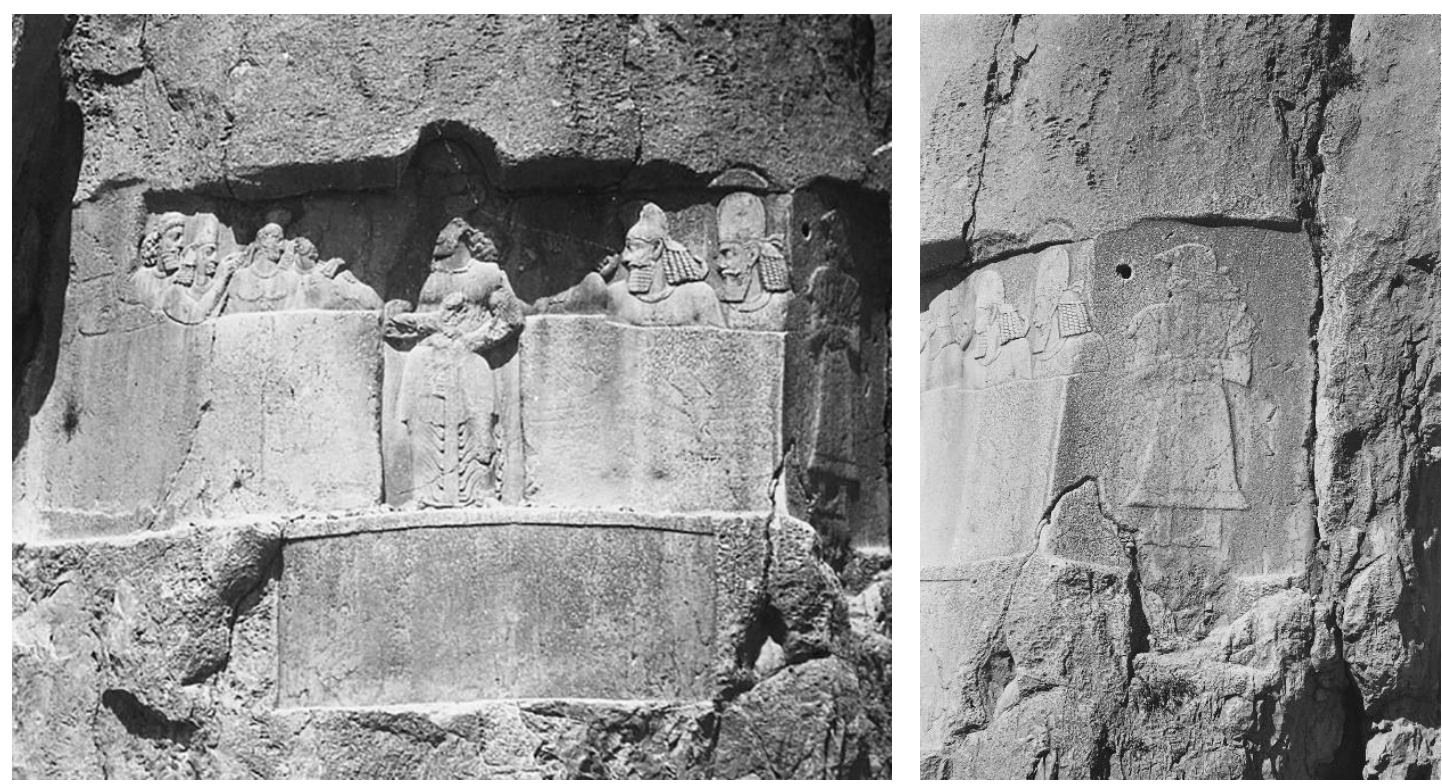

Fig. 7 (left) Naqsh-i Rustam: Bahram II and court, carved over an Elamite relief. Photograph: (C) Freer Gallery of Art and Arthur M. Sackler Gallery. Fig. 8 (right) Naqsh-i Rustam: Sassanid reliefs depicting Bahram II among his family and courtiers: detail view of an Elamite sculptured scene. Photograph: C Freer Gallery of Art and Arthur M. Sackler Gallery archives.

Achaemenid-inspired language of the inscription, the Sasanian protocol calling for sheep, bread and wine has a remarkably close ancient counterpart. Elamite tablets from the Perspolis Fortification Archive refer to the funerary monuments of the Achaemenid kings and the cult around them for the benefit of the king's soul, including rations for the upkeep of the officials in charge and animals for sacrifice at the tombs. ${ }^{77}$ Moreover, we see Elymais as a semi-independent state frequently subject to the Parthian state, which existed between the second century BCE and the early third century CE in the territories of Susiana, in southwestern Persia. Most of the Elymaeans were probably descendants of the Elamites who had occupied these same territories in earlier centuries. The conquest of Ardashir in $221 \mathrm{CE}$ marked the end of Elymais as a political state. ${ }^{78}$ Thus, it was likely that Elamite was not unfamiliar to the Sasanians and they likely regarded them as an old predominant reign of southwestern Iran.

Although very badly mutilated, the Elamite rock reliefs at Naqsh-Rostam illustrate the persistence of holy sites. To one scene carved in the Old Elamite period Neo Elamite artists have added two figures, probably the king and the queen, but this group has been

${ }^{77}$ Canepa 2010, 582.

${ }^{78}$ Hansman 2011. 
largely obliterated by a relief of the Sasanian king Bahram II. ${ }^{79}$ Although it differs stylistically from the Achaemenid reliefs on the cliff nearby, it is possible that Bahram II valued this ancient relief as a remnant of his ancient Persian ancestors. In this case, Bahram II's relief compelled the ancient figure to perform compositionally and ritually in his contemporary courtly scene: the remaining Elamite figure (Fig. 8) starts the line of courtiers turned toward the king at the centre, with all Sasanian figures following his profile composition. ${ }^{80}$

On this rock relief, which is $5.4 \mathrm{~m}$ long and $2.5 \mathrm{~m}$ wide, Bahram II stands in frontal view with his head, in the direction of the Elamite king's sight, turned to his right towards his family. Next to him on his right are depicted the busts of the queen, then two senior princes and behind them Kartir, recognizable by the shears on his hat. The last person is Bahram II's uncle, Narseh. Depicted to the left are three courtiers. ${ }^{81}$ Not only are all the personages attending the king represented only as busts, but the area immediately beneath the scene has also been smoothed in readiness for an inscription, which, unfortunately, was never inserted. This rock relief was carved after Kartir's reliefs at Naqsh-e Rajab, Naqsh-e Rostam (inside Shapur I's relief) and Sar Mashad. ${ }^{82}$ Paying close attention to the rock relief reveals surprising details. In the space between Narse's curly hair and the top of the rock relief it is possible to discern a carved shear (Fig. 9), as Kartir aimed to state that in fact this rock relief was carved following his idea and is a memorial to himself. ${ }^{83}$

Kartir undertook to perpetuate his achievements on the great rock walls. Few, if any, notable priests in the world's history have used up so much space on stone. His inscription in Naqsh-e Rajab states his interest in perpetuating his achievements:

... and for me the great glory of my own name on imperial deeds and documents stands written, that whoever in future time imperial documents or deeds or other screeds may see, that one should know, that I am Kartir, who... ${ }^{84}$

Similarly, regarding Kartir's power during Bahram II's reign it was natural for Kartir to impose his idea on Bahram II's rock relief and the carved shear inside the rock relief might be the symbol left by him for future viewers to recognize and appreciate him. As a result, we can expect to recognize some features of Kartir's surreal view in this rock relief as well.

\footnotetext{
79 Vallat 2011.

80 Canepa 2010, 586.

${ }^{81}$ Hinz 1969.

${ }^{82}$ Herrmann 1970, 168.

${ }^{83}$ Hinz 1969.

${ }^{84}$ Sprengling 1953, 67.
} 


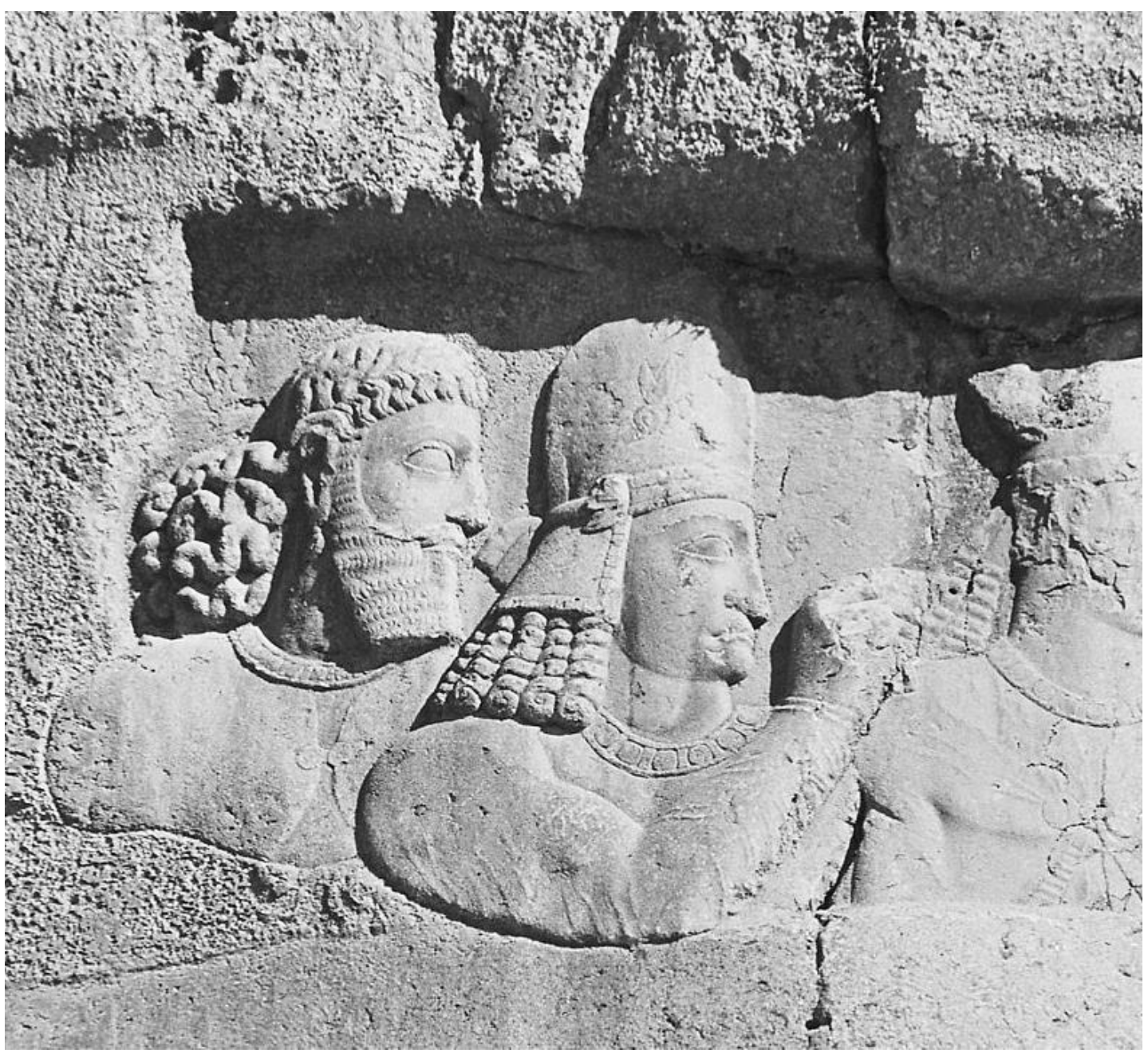

Fig. 9 Naqsh-i Rustam: detail view of Sassanid reliefs depicting Bahram II among his family and courtiers. Photograph: (C) Freer Gallery of Art and Arthur M. Sackler Gallery archives.

Leaving the Elamite king's figure safe on the right side of the Bahram II's rock relief indicates that not only was there not any hostile treatment against the existing rock relief to completely destroy it, but the placement of Bahram II's rock relief demonstrates the intentional function of inserting one rock relief into part of the existing one. In this way, we again see the bust figures. A similar scene of Bahram II at Naqsh-e Bahram and his other rock reliefs indicates that depicting bust figures on rock was not a current style of carving rock reliefs during Bahram II's reign. At Naqsh-e Bahram in Fars, Bahram II is 


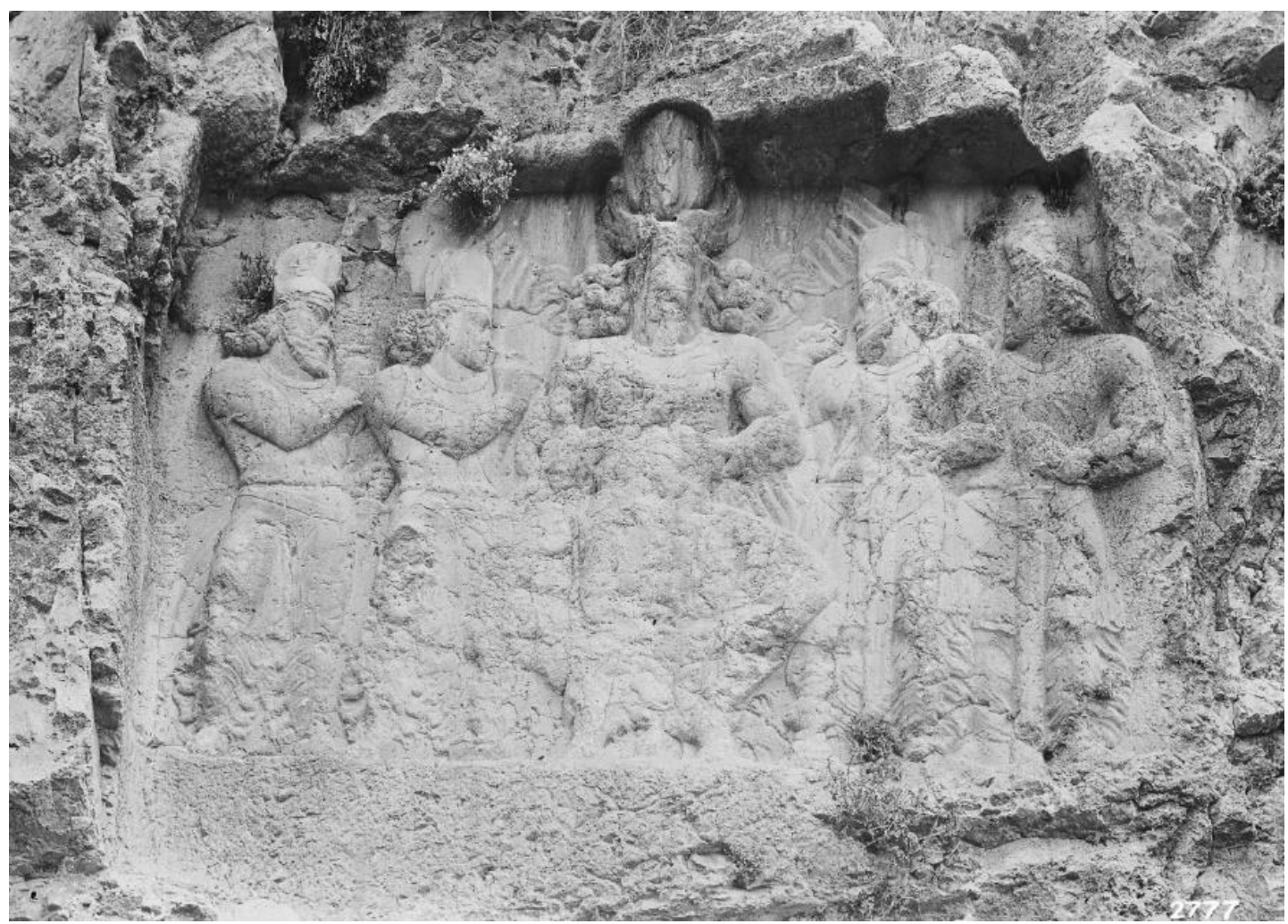

Fig. 10 Naqsh-i Bahram: Sassanid reliefs depicting Bahram II seated in full front view, flanked by Kartir and Papak, satrap of Georgia, on his left and two other dignitaries on his right. Photograph: (C) Freer Gallery of Art and Arthur M. Sackler Gallery archives.

shown in the centre of the scene, enthroned with knees apart (Fig. 10). He looks neither to right nor left, only stares out to the front. Four nobles with hands raised in respect are portrayed in the usual Sasanian stance, full length, two on either side of him. ${ }^{85}$ Consequently, Bahram II's rock relief at Naqsh-e Rostam seems like a strange and unexpected combination offering destruction of space and time.

The surreal element in surrealism was not really a style, but an attitude towards the source of the illusion to be visualized. The artist was as much surprised and arrested by the discovery of his vision as were the viewers. The surrealists found in dream a key to the expansion of the self. He or she came to delight the senses, to coax them from the high seriousness of their mundane state, and to amplify the self to a greater and more dynamic self-awareness. ${ }^{86}$ Not only did Kartir perform a visionary journey to regain

${ }^{85}$ Herrmann 1970, 169.

${ }^{86}$ Dedrick 1975, 5. 
confidence in the correctness of the traditional ritual practices in a time of doubt, ${ }^{87}$ but his bust figures added to the previously Sasanian rock reliefs and his vast inscriptions were argued to have been traits indicating his interest in visualizing his illusion just as surrealists would have done.

While Kartir repressed other religions, as he cites in his inscriptions, he was not a warlike man to the extent that Kartir and two kings under his influence, Bahram I and his son Bahram II, represented a revolution against the character of Shapur I. As Kartir makes it clear, under Bahram I he attained the opportunity he had been striving for in vain under Shapur I and Hormizd I. Outside wars, conquests and missions are given up. The ageing Bahram I is soon weary; he dies in 275/6 CE. Kartir's mind controls the moves. Bahram II, son of Bahram I, is placed on the throne. He is known as a weakling, a wastrel, a voluptuary and a drunken sot. So, Kartir takes control of him, body and soul, and receives for his efforts the epithet 'soul saviour of Bahram'. This goes on for 17 long years. In his time the sturdy old soldier-emperor Carus makes his march on Ctesiphon. As with many others it availed him nothing and proved to be his undoing, even though Iran was quite unwarlike at the time. That was in $293 \mathrm{CE}$. For a little more than ten years thereafter nothing happened between Rome and Iran. Kartir tried to enthrone Bahram II's son as Bahram III after Bahram II died, but Narseh was better prepared and took the throne. By 296 CE Narseh felt strong enough to attempt a resumption of his father's earlier warlike policy against Rome. Kartir was completely eliminated from the official records and an attempt was made to wipe out Bahram II. ${ }^{88}$

\section{Conclusion}

This article was an attempt to cast light on the anti-war character of Kartir, whose attitude towards leaving monuments of himself appears to have points in common with the surrealism movement of the early twentieth century, at least from the social and artistic perspectives. Whether it happened intentionally or unknowingly, Kartir's rock reliefs reveal some visual reflections of the unconscious mind related to the Sasanian Empire.

Mohammad Soltani

Independent researcher

E-mail: mohammad_soltani1977@yahoo.com

87 Skjærvø 2012.

88 Sprengling 1953, 110. 


\section{Bibliography}

Antle, M. 2006: 'Surrealism and the Orient', Yale Fr. Stud 109: 4-16.

Brosius, M. 2006: The Persian Empire from Cyrus II to Artaxerxes I, London: London Association of Classical Teachers.

Breton, A. 1969: Manifestoes of Surrealism, translated by R. Seaver \& H. R. Michigan: Lane, Michigan Press.

Bauduin, T. M. 2014: Surrealism and the Occult, Amsterdam: Amsterdam University Press.

Barrow, R. 2005: 'From Praxiteles to De Chirico: Art and Reception', IJCT 11 (3): 344368.

Canepa, M. P. 2010: 'Technologies of Memory in Early Sasanian Iran: Achaemenid Sites and Sasanian Identity', AJA 114 (4): 563-596.

Clifford, J. 1981: 'On Ethnographic Surrealism', Comparative Studies in Society and History 23 (4): 539-564.

Daryaee, T. 2000: 'Shamanistic Elements in Zoroastrianism: The Pagan Past and Modern Reactions', Pomegranate 13: 31-37.

Daryaee, T. 2001: 'Kartir's Inscription in Naqsh-e Rajab’, International Journal of Ancient Iranian Studies 1 (1): 3-10.

Daryaee, T. 2009: Sasanian Persia: the Rise and Fall of an Empire, London: I. B. Tauris.

Dedrick, P. H. 1975: 'The Surreal and Surrealism', JGE 27 (1): 1-5.

Frye, R. N. 1949a: ‘An Epigraphical Journey in Iran’, Archaeology 2 (4): 186-192.

Frye, R. N. 1949b: 'The Middle Persian Inscription at Sar Mashhad', HTR 42 (1): 69-70.

Garthwaite, G. R. 2005: The Persians, Malden: Blackwell Publishing. 
Gignoux, P. H. 2011: 'Arda Wiraz', Encyclopedia Iranica, Online Edition.

http://www.iranicaonline.org/articles/arda-wiraz-wiraz (Accessed August 11, 2011)

Gignoux, P. H. \& Litvinsky, B. A. (eds) 1996: 'Religions and Religious Movements-I', in: Litvinsky, B. A, Zhang Guang-daand \& R. Shabani Samghabadi (eds). History of Civilizations of Central Asia: The Crossroads of civilizations, A.D. 250 to 750, vol. 3, Delhi: Banarsidass, 401-410.

Godard, A. 1965: L'art de l'Iran, translated by Heron. M, London: George Allen \& Unwin Ltd.

Hansman, J. F. 2011: ‘Elymais’, Encyclopedia Iranica, Online Edition. http://www.iranicaonline.org/articles/elymais (Accessed December 13, 2011)

Harper, P. O. 2011: 'Art in Iran v. Sasanian Art', Encyclopedia Iranica, Online Edition. http:/ /www.iranicaonline.org/articles/art-in-iran-v-sasanian (Accessed August 15, 2011)

Herrmann, G. \& Curtis, V. S. 2002: 'Sasanian Rock Reliefs', Encyclopedia Iranica, Online Edition.

http://www.iranicaonline.org/articles/sasanian-rock-reliefs (Accessed July 20, 2002)

Herrmann, G. 1970: 'The Sculptures of Bahram II', JRAS 2: 165-171.

Herzfeld, E. 1941: Iran in the Ancient East, Oxford University Press: London. Hinz, W. 1969: Altiranische Funde und Forschungen, Walter de Gruyter: Berlin.

Hodapp, W. F. 2009: 'The Real and Surreal in Medieval Dream Vision: The Case of James I's Kingis Quair', Journal of the Midwest Modern Language Association 42 (1): 55-76.

Jean, M. 1975: 'Views on Surrealist Art', JGE 27 (1): 7-20.

Levi-Strauss, C. 1963: Structural Anthropology, New York: Basic Books.

Luschey, H. 2011: 'Ardashir I ii. Rock Reliefs', Encyclopedia Iranica, Online Edition. http://www.iranicaonline.org/articles/ardasir-ii (Accessed August 11, 2011)

Macdermot, B. C. 1954: 'Roman Emperors in Sassanian Reliefs', JRS 44: 76-80. 
Moyne, J. A. 1974: 'Sasanian Pahlavi Inscriptions: A Concordance', Computers and the Humanities 8 (1): 27-39.

Nyberg, H. S. 1960: 'The New Corpus Inscriptionum Iranicarum', BSOAS 23 (1): 4046.

Porterfield, A. 1987: 'Shamanism: A Psychosocial Definition', AAR 55 (4): 721-739.

Potts, D. T. 2004: The Archaeology of Elam, Cambridge: Cambridge University Press.

Rawlinson, G. 1884: The Seven Great Monarchies of the Ancient Eastern World, vol. 3, New York: Millar.

Shahbazi, A. S. 2005: 'Sasanian Dynasti', Encyclopedia Iranica, Online Edition.

http://www.iranicaonline.org/articles/sasanian-dynasty (Accessed July 20, 2005)

Shahbazi, A. S. \& Klima, O. 2011: 'Bahram II', Encyclopedia Iranica, Online Edition. http://www.iranicaonline.org/articles/bahram-the-name-of-six-sasanian-kings (Accessed August 24, 2011)

Skjærvø, P. O. 2008: Introduction to Zoroastrianism, Cambridge: Cambridge University Press.

Skjærvø, P. O. 2012: 'Kartir', Encyclopedia Iranica, Online Edition.

http://www.iranicaonline.org/articles/kartir (Accessed April 24, 2012)

Sprengling, M. 1953: Third Century Iran: Sapor and Kartir, Chicago: University of Chicago Oriental Institute.

Tanabe, K. 1990: 'The Lions at Sar Mashad and The Lion-Hunt of Bahram II', AlRafidan 11: 29-43.

Vallat, F. 2011: 'Elam vi. Elamite religion', Encyclopedia Iranica, Online Edition. http://www.iranicaonline.org/articles/elam-vi. (December 13, 2011) 